低出カレーザー光照射後のラット総頸動脈の組織学的検討

\title{
Histological Evaluation of Rat Carotid Artery Wall to Low-Power Laser Irradiation
}

王天明, 口脇博治, 木野本武久, 橋詰良夫, 景山直樹, 宮崎保光*

Tianming Wang, Hiroji Kuchiwaki, Takehisa Kinomoto, Yoshio Hashizume, Naoki Kageyama, Yasumitsu Miyazaki * 名古屋大学脳神経外科第一病理， *豊橋技術科学大学情舎工学系

Nagoya University * Toyohashi University of Technology.

\begin{abstract}
In order to evaluate the safty of the noninvasive laser-doppler-velocimeter that authors are trying to develope, this study was disigned to investigate the histological change of the arterial tissue following irradiation of laser in vivo.

Common carotid arteries of 74 rats (weight $200 \mathrm{~g}$ ) were irradiated unilaterally with a He-Ne laser (NEC GLG 5700 model, wave length $633 \mathrm{~nm}$, power output $27 \mathrm{~mW}$, focus diameter $200 \mu \mathrm{m}$ ) for $5,15,30,60,120$ minutes, respectively, and the histological examination of the artery walls was carried out in 48 hours (acute stage), 1 week (subacute stage) and 4 weeks (chronic stage) after irradiation.

According to irradiation power, the rats were divided into two groups: the full power $(27 \mathrm{~mW})$ group and the half power group. Each evaluation consisted of two or three rats. The contralateral common carotid arteries were taken as the control.

Degenerative changes, especially in the middle layer of the artery wall, were found in all the full power group rats and in some of the half power group rats irradiated more than 60 minutes.

It seemed that these pathohistological changes became more remarkable with the longer irradiation time.
\end{abstract}

1.はじめに

低出力レーザーの医学的応用はすでにいくつか の分野で成果をあげつつある。即ち呧出力レーザ 一誘発光化学効果 $\left.{ }^{3}, 9\right)$ 亿よ瑟性腫㻛に対する治 療や，鍼の代りに低出力レーザーの生体に対する 刺激効果を利用する跭痛の治瑔とか, 低出力レー ザ一の血管吻合への応用などである。著者らは低 出カレーザー光線を用いてレーザードップラー法 により生体に対し無侵留で血流計測を目的とした
計測器の開発を試みている。ての際問題となるの は, 低出力レーザー光照射が生体の血管に対して どの筑囲で（出力と照射時間，即ち血管にどれは どのエネルギーを与えるか）適用すれば然害であ るかを検討するてとであり，てのため以下の実験 モデルを用い検討した。

\section{2. 材料及び方法}

Wistar rat ( $8200 \mathrm{~g}$ weight ) 計 74 須を用い, 
3. 結 果

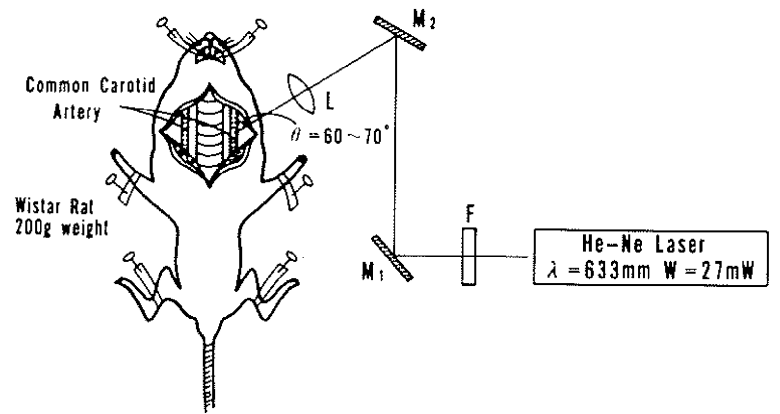

図 1 . 実験装置

F：透過率可変 filter

$\mathrm{M}:$ Mirrow

L : Lens

$\theta:$ レーザー光照射角度

充分なネンブタール腹腔内麻酔にて, 図 1 のよう な方法で，しっかり固定し，局所を清潔保ちな がら，手術䫓微鏡下で両側総頸動脈を充分露出し た。一方の総頚動脈壁にレーザー beam をレンズ （L）で，直径約 $200 \mu \mathrm{m}$ まで絞り，60-70度 の角度で照射した。福本作成時照射部位の 同定が容易になるように標的部位の筋肉に無菌系 で標識をつけた。照射中の钼祭は実体顕微鏡によ って行ない，以下に述べる急性期の変化はての観 祭結果をも含めた。

レーザー光 (NEC 製GLG5700 型 $\mathrm{He}-\mathrm{Ne}$ レー ザー, 波長 $633 \mathrm{~nm}$, 出力 $27 \mathrm{~mW})$ は透過率可変 filter $(F)$ を用い $27 \mathrm{~mW}$ のull power 群とそれの half power 群に分けた。照射時間は $5,15,30,60$, 120 分とし, 各 stage は 48 時間以内急性期とし, 西 急性期は一週目，慢性期は 4 週目として動哌壁の組 織变化を㛟討した。各群の各stageの各照射時間 帶で検討した動物は 2 3匹である。それぞれの動 物における対照血管としては，同一 rat で同じ条 件下の非照射㑡総頸動脈を用いた。血管摘出標本 をformalin で固定した後, Hematoxylin-eosin (HE) 染色と, 一部で Elastica van Gieson （EVG）染色にて連続横断切片の標本を検討する と同時に電顕標本も作成したが，今回はまず光顕 レベルの検討結果を報告する。
今回の実験で, 急性期から慢性期を通じて各群 全例の非照射側血管垶はすべて異常変化が認めら れなかった。又照射中血管の表面の焼灼及びこれ に基く変形・出血・血管破損などの所見もなかっ た。照射された rat の死亡例はなかったが, 約10 \%に局所の感染が見られた。しかし血管そのもの に対する圧迫，血栓形成や炎症などの及んだもの はなかった。西急性期，慢性期 rat 共血管周囲に 癒着が認められたが，検討の対象として不適切な 例は認められなかった。

照射側の血管標本を検討するとそのいくつかに 病的組織像が見出された。

まず照射光の powerにおける病変像の分布を見 ると，full power 群の照射時間 5 分を越えた各 stage の照射㑡標本には病変が認められた。そし て half power 群では照射時間 60 分を越えた各例 にも病変像が見られた。

その組織変化の程度と照射時間との関係を検討す ると, 照射時間の長い程著明になる傾向が認めら れた。

組織学的変化存有する病像が各 stage において それぞれの特徵を持つように見える。即ち，急性 期では血管の中膜及び内膜の著明な浮嗹状が主な 表現となる。図2 はその組織学的変化を示す典型 例である。乙の例は half power群120分照射例の 照射側血管の急性期変化を示す標本である。矢印 で示す照射部位に中膜の平滑筋細胞の核が消失し, 細胞が浮腫状となっている。乙れに接する内膜も 厚くなり浮腫状を呈した。弾性線維染色標本では 血管壁の浮腫のため, 弾性線維の太さは変わらな いがその密度は粗になり，正常血管弹性線維の波 形構造を失い，伸展された状態を呈している。

亜急性期となると各群に共通した興型変化とし て血管壁中膜の浮腫がまだ残っているが内側の弾 性線維がや々太くなり，その間の平滑筋細胞が消 失した。

更に慢性期に移るとその組織変化の特徵として は欰管壁の浮腫が消失し，弾性線維は目立つよ 

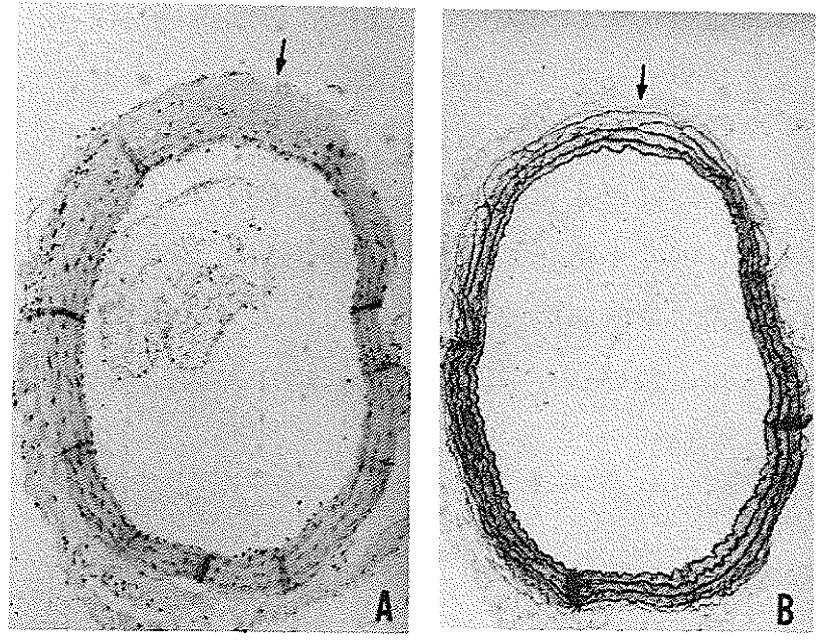

図 2. Half power 群 120 分照射急性期血管 組織像

A : Hematoxylin-eosin 染色 $\times 100$ 矢印で示す部位には血管中膜の平滑筋細胞 の核が消失し, 細胞が浮腫状となっている。

B : Elastica van Gieson 染色 $\times 100$ 血管壁の浮腪のため, 弾性線維の密度は粗 になり，正常の波形構造を失い，伸展され た状態を呈している。

うになりその間の平滑筋組織が完全に吸収され，血 管壁がや〉薄くなった。

各群を通じてどの時期における照射部位にも細胞 增殖などの変化は認められなかった。これらの組織 病変は従来の病理学的炎症治㾪過程にあてはめて考 慮すべきかどうかが多少哫問であるが刺激効果と言 うより,むしろ退行変性の過程にあるものとの珰織 が成り立つと考光られる。

\section{4. 荐祭}

$\mathrm{He}-\mathrm{Ne}$ レーザー光は発振光の質が良く，取扱い も簡単で, 最もポピュラーなレーザー光として医学 領域に応用されている。特にその光は生体組織への 浸達性が良く ${ }^{5,8)}$ ，低出力で比較的深い部分に影悡 を与えることが出来て，レーザー鍼 (Laser acupuncture $2 \sim 5 \mathrm{~mW})^{8,10)}$ や創賃治瘾促進 $(5 \mathrm{~mW})^{8)}$ にも用い ている。また眼科における視力と眼屈折率の测定, 眼底血流速度の測定にも使用されている ${ }^{7,8)}$ 。

これらの場合には出力はいずれも小さくて $(<5$ $\mathrm{mW}$ ）連続照射時間も比較的短い。とのためそのは
とんどが生体に対して無害と考えられ組織損 害な ぞのdemeritsについては検討されていない。特 にレーザー光照射による生体一の影響が詳細には 不明な現時点で急性変化に限らず慢性変化を検討 するととはこれからのレーザー応用機器の基礎と なる重要な問題を含んでいると思われる。

今回著者らが用いた $\mathrm{He}-\mathrm{Ne}$ レーザー出力は full powerは $27 \mathrm{~mW}$ であり上述の用途のレーザー 出力に比べ強い power 有する。

更にてれを単位面積あたりの power density 概算し、 spot diameter をレンズで $200 \mu \mathrm{m}$ まで 皎った場合, 約 $90 \mathrm{~W} / \mathrm{cm}^{2}$ となる。しかし $\mathrm{He}$ N eレーザー光の組織透過率は高くても, 血管壁の エネルギー败収率を5-10\%とすると， power densityは 4.5〜 $9 \mathrm{~W} / \mathrm{cm}^{2}$ となってしまう。更に 照射時間を 5 分 ( $300 \mathrm{~S})$ 加 120 分 $(7200 \mathrm{~S})$ と延長することにより照射部位のエネルギーは $1350 \sim 2700 \mathrm{~J} / \mathrm{cm}^{2}$ 加 $32400 \sim 64800 \mathrm{~J} / \mathrm{cm}^{2}$ とばく大なものになってしまう 今回のLaser irradiation での病巣はこのような エネルギー照射のもとで形成されたととになる。

今回の実験に認められた血管垶の組織变化を生 じた可能性のある原因としては,(1)レーザー光照 射によるもの，(2)血管莡露出時の或は血管摘出時 の血管に対する機械的損仵, (3)感染によるものな どがあげられる。

今度の所見の特幑をまとめると，〈1〉病変は血 管横断面の一力所にあり，しかもその筑囲は大抵

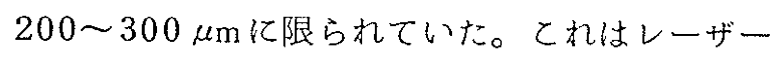
beam の太さとほぼ一致している。〈2〉病的所見 は非照射側に見出されなかった。〈3〉病変の性質 に関しては, 炎症性というより, むしろ退行変性 のようなものと考えられる。〈4〉病変は照射光の 出力と照射時間との間にある関係老持つ上うに見 える。こう考えると、レーザー光照射により生じ たものとの可能性が強いと思われる。

今度の病変は炎鿊性のものでないととは明らか であるから，全例の $10 \%$ は肉眼的に被っていた 頸部筋肉, 特に系結びの標識を中心とした部分に 感染・炎定が認められ，でも血管に及んだもので 
はなかっので，炎症によるものとは考えにくい。

機械的損傷とすると, 両側血管に同じ頻度に起 るはずであったが，実にも血管外膜は両側とも損 傷を加えていた。だから血管外膜についての検討 は出来なかった。但し, 中膜に認められた病変は 照射側にしか認められなかったので一概に機械的 損傷とは言い難い。

生体組織はレーザー光照射される場合に，その 波長によって生ずる反応が異なる。それに同一レ 一ザー光照射に対しても各種の組織の光吸収率も 反応も一致とは限らない。今度の実験に，血管壁 がどのような機序でてういう反応を生じたかがま だ明らかでない。今後更に検討する必要があると 考えている。今回の実験の結果によって $27 \mathrm{~mW}$ の half power を用いても連続照射時間が 60 分 を越えると血管そのものにむしろ退行性変性よう の変化を認めたてとになるので, 例え検査に用い る場合でもその出力や時間的配分を考慮すべきで あると考觉られた。

\section{References}

1. Fox JL, Hayes JR, Stein MN: Experimental cranial and vascular studies of the effects of pulsed and continuous wave laser radiation. J Neurosurg 27: 126-137, 1967

2. Yoshii Y, Egashira T, Maki $Y$ : Use of evoked responses to measure laser photoradiation tissue effects. Neurosurgery 14: 131-134, 1984

3. Edwards MSB, Bogan JE, Fuller TA: The laser in neurological surgery. J Neurosurg. 59: 555-566, 1983

4. Toya S, Kawase T, Iisaka Y, et al.: Acute effect of the carbon dioxide laser on the epicerebral microcirculation. J Neurosurg. 59: 193-197, 1980
5. 池田 公, 口脇博治, et al : レーザードッ プラー法による血流速測定の武み。

日本臨床 43. №.2 71-75. 1985 .

6. 江頭泰平, 吉井与志彦, 牧 豊: アルゴン・ レーザーに上る脊靕傷害後の生理機能変化に 関する基礎的研究,

日本レーザー医学会誌 6 №.2 23-27. 1985 .

7. 北沢克明, 白土城明：レーザーの眼科応用, 日本レーザー医学会誌 5 Vol. 1, 8-13，

1985 .

8. 久保宇市：医用レーザー入門， オーム社, 東京 1985 .

9. Dougherty, T.J., Kaufman, J.E., Goldfarb. A, Weishaupt, K.R. et al.: Photoradiation therapy for treatment of maIignant tumors, Cancer Res., 38: 2628-2635, 1978

10. 神川喜代男：レーザー学会学術講演会第 3 回 年次大会講演予稿集, p 179(1983). 